\title{
PopUlism ANd Political Elites
}

\author{
Jan Pakulski*
}

\section{Abstract}

Contemporary populist movements - outlined as an ideal type (anti-elitism, demagogy, "citizenism", conspiratorial views, and embrace of simple solutions) - are analysed according to the Weberian approach that focuses on leadership groups: their styles, structures, rhetorics, and the relationship with followers. Populist leaders emerge - and populist movements appear at the times of rapid social change and the accompanying crises. But they also herald the decline of trust and moderation among the leaders and activists. This decline results in deep divisions and antagonisms within political elites which is reflected in populist styles rhetoric. Populist ascendancy is accompanied by degeneration of political elites and political decay, that is weakening the core political institutions of the state, rule of law, and democratic accountability.

Keywords: populism, populist movements, leadership, anti-elitism, demagogy, elite degeneration, political decay

Creating the English-language version of the journal "Zoon Politikon" is financed under contract No. 724/P-DUN/2018 from the funds allocated by the Minister of Science and Higher Education for dissemination of science.

\footnotetext{
*Professor Jan Pakulski, University of Tasmania, Hobart, Australia and Collegium Civitas, Warszaw, Poland,
} e-mail: jan.pakulski@utas.edu.au |ORCID: https://orcid.org/0000-0003-0597-5547 
A powerful wave of "populism" is sweeping through all highly developed societies in Europe and North America. Populist leaders are well-established political figures in almost all developed countries, although only in the USA, Italy, Hungary, Poland, Slovenia and the Czech Republic they lead governments. Donald Trump emerged unexpectedly as the US populist president after what is described as a takeover of the Tea Party movement and exceptionally demagogic campaign. Matteo Salvini, leader of The League - and now of government in Italy - rules in collaboration with Luigi Di Maio, who heads the chaotic Five Star Movement. In Central-Eastern Europe populist leaders wield executive power in Hungary (Viktor Orbán), Poland (J aroslaw Kaczynski, though behind the scene), Czechia (Milos Zeman and billionaire Andrej Babis) and Slovenia (Janez Jansa). They are more than a dozen other less prominent but highly influential populist leaders in Europe: Marine Le Pen the head of the National Rally (formerly the National Front) in France competing with J ean-Luc Mélanchon, the founder and leader of left-wing Un-submissive France; Geert Wilders of the Dutch Party of Freedom; Jimmie Akesson of Sweden Democrats; Albert Rösti of the Swiss People's Party; Kristian Thulesen of the Danish People's Party; Alexander Gauland and Alice Weidel the co-chairs of Alternative for Germany (AfD), to name only a few.

The scale of support (participation and political backing) for populist leaders and movements is difficult to assess. Since the early 1970s, European populist right-wing movements and parties (mainly anti-immigrant/ anti-minority and anti-EU, such as the National Front/ Rally in Franceand British UKIP) have doubled the proportion of electoral votes and control an average of $14 \%$ of seats in national parliaments. The support for left-wing populist parties (mainly anti-globalization, anti-EU and anti-austerity such as Greek Syriza or Spanish Podemos) has increased fivefold, and their average number of parliamentary seats exceed $12 \%$. It should be noted that the data do not include support for 
social movements and local initiatives, which - as shown by the results of the presidential elections in Hungary, Poland, the US and Austria, as well as the outcome of the Brexit referendum in the United Kingdom comprise nearly half of the citizens (Barr 2009; Betz 1994; Canovan 1981; 2004; Mudde 2015).

This unexpectedly powerful surge poses analytical and theoretical challenges for contemporary sociologists: how should one accurately describe and explain these leader-centred contestatory mobilizations? As expected, there is no dearth of descriptions and political explanations of populism, but sociological explanations, especially those treating populism as a form of mass socio-political movement and leadership style, are sparse (Della Porta, Diani 1999; Pakulski 1991; Smelser 1981).

Ronald Inglehart and Pippa Norris (2016), for example, attribute the rise of populist leaders and their mass following to increasing economic inequalities that foster a sense of widespread insecurity, as well as to cultural backlash, mainly among older and more conservative persons, against value change towards "post-materialism" (2016, pp. 11-14). However, such explanation fails in explaining why populists gain mass support among so many young people, and why they are more prominent in some countries than others, especially in such (relatively) economically successful countries, as Poland, Hungary, Czech Republic or Slovenia. The value-change and grass-root explanations need to be supplemented with explanations that place political leaders and their massmobilizing rhetoric at the centre of attention.

But one must start with some clarifications. The term "populism" and "populist leaders" must be defined with more precision. It first appeared at the beginning of the last century against the backdrop of analyses of fin-de-siecle "peasant" parties, anti-capitalist ideologies in Eastern Europe and anti-industrial (anti-modernist) socio-political movements in the US (Populist Party). In the 20th century, it was applied to describe a wide variety of phenomena, from popular views or 
ideological visions to social movements, political styles, types of leaders and political regimes, such as Nazism, Maoism, or "Peronist nationalism" of South America. Today, this term appears mainly in relation to contestatory socio-political movements, both "right-wing" (e.g. the Tea Party in the US) and "left-wing" (e.g. movements united within the Greek Syriza). It is also used for parties and charismatic leaders spawned by these movements. Below we propose the use of this term in reference to social movements and leadership style. They share several important features that, put together, make up a certain ideal type. They all:

- appeal to anti-elite "citizenism", that is, promote popular political engagement through the contestation of the socio-political order and ruling elites and divide citizens into two opposing camps: "ordinary citizens" versus exclusive, corrupt "ruling elite" with its privileged beneficiaries (urban intelligence, finance, etc.);

- employ demagogy, that is, highly emotive accusations and condemnations, mobilize resentments, as well as manipulate mass fears and hopes;

- claim to be the authentic voices and sole representatives of "simplefolk", "ordinary patriots" and "honest citizens" ignored by proglobalist "ruling elites" and corrupt "establishments". Other elite critics are portrayed as imposters;

- blame the "ruling elites" for real and imagined failings associated with globalization: high unemployment, an uncontrolled influx of refugees, "Islamization", degradation of social security, ethnic crime, etc. Anti-elitism combined with anti-global nationalism is the main, universal and powerful reference in populist leaders' demagogy;

- these interpretations are paired with equally simplified remedies: replace the cosmopolitan ruling elites with patriotic representatives of the "people", reveal "the culprits", and empower those 
who promise to punish the guilty. Only in this way, they claim, can one quickly rebuild social cohesion, regain the lost popular (and national) sovereignty, strengthen democracy and restore social justice (e.g. Gerbaudo 2014, Mudde 2015, Muller 2016). Such a take on populist movements - as a Weberian ideal type that focuses on leadership style and rhetoric - facilitates the analysis of both mass mobilizations that accompany the ascendancy of populist leaders. In accordance with the Weberian analytic tradition, it is political leaders that are seen as the key actors on political scene and the man "mobilisers" of mass followers. Leaders' pronouncements and their relations with "staffs" and supporters are key explanatory variables.

The anti-elitist demagogy of populists attracts mass following and triggers what is often described as "contentious politics" or "politics of resentment". It involves the widespread use of demagogic disinformation and manipulation of resentments combined with promotion of "quick and simple" remedies. The populists arouse resentments (against ruling elites), strengthen fears (of "oligarchic corruption" or "invasions" by culturally "foreign" immigrants), and then raise hopes for quick fixes to the problems ("good change").

Such a demagogic manipulation needs the help of social and media channels. The role of the former is taken by informal "circles of concerned people". The latter are represented by both "old media", such as radio and television, and - increasingly - the social media, like Facebook and Twitter. While television is effective in mobilizing support based on identification with leaders, social media, serve well disinformation as well as manipulation of emotions (flaming). The Internetbased new social media are extremely effective in building "closed communities of inquiry", isolated from critics, as well "homophilic information networks", i.e. contact networks of people who send each other likeable and selective information and interpretations ("The Economist" 2016). Such communities and networks, often overlapping with 
faith-based organisations, become the social basis of modern populist movements in developed countries.

Populist movements vary in issues they publicise. What they all have in common, however, rare threads of demagogic anti-elitism, presented as democratic egalitarianism, and xenophobic nationalism (in the typical disguise of patriotism) fixated on opposition to liberal globalisation. The dominant issues publicised of Donald Trump and the Tea Party activists in the US are illegal immigration (mainly from Mexico) and "export of industry and jobs" (mainly to China) - both phenomena associated with globalization and both flying in the face of the slogan "America First".

In Great Britain, the themes of immigration dominate debate, as shown by pro-Brexit campaigns by Nigel Farage and Boris J ohnson. In France, the nationalist supporters of Marina LePen manipulate the sense of national pride, Islamophobia and the fear of terrorism. In the Netherlands, Geert Wilders threatens the compatriots with a flood of "North African refugees" portrayed as potential "Islamist terrorists". For Spanish populists led by Pablo Inglesias, the major threat is represented by Muslim refugees "invited by the liberal elite", as well as by Eurocrats who impose the destructive "austerities" on economically dependent nations. Greek populists are divided into supporters of the Golden Dawn and the anti-globalisation coalition of Syriza. Jaroslaw Kaczynski warns against "Islamic" refugees, "gender ideologies" and the unspecified category of "thieves" and "communists", which covers all critics of the ruling Law and J ustice parties.

How to explain the contemporary wave of mass mobilizations? On the one hand, modern populist mobilisations are disturbingly similar to the "first wave of populist movements" from the 1920s and 1930s: national-socialist, fascist and Bolshevik. This similarity tempts us to embrace those interpretations that portray populism as ideological extremism, like in the Smelser's "collective behaviour" school. 
On the other hand, modern populist leaders are much less ideological, their views are less cohesive than those of the "first wave" populists, and they are more favourable to democracy (though often anti-liberal) than the views of the early 20th century populist leaders. Marxist interpretations that portray populist leaders and movements in terms of class interests and conflicts, turn out to be equally dubious. So are the rationalistic interpretations (resource mobilization, political process) popularized mainly by American researchers of reformist mass movements in the 1960s and 70s. It is true that populist leaders often form parties and participate in governments, but they also use anti-establishment demagogy. They challenge the politics of the established parties and elites in a radical, ideologically incoherent and unpredictable way.

This incompatibility of old sociological theories does not mean that our analytical and theoretical repository of knowledge is of little use in tackling contemporary populism. The very ideal type of "populist style of leadership" we have suggested above contains a clear reference to the sociological tradition that was formed in the confrontation with the "first wave" of populism at the beginning of the 20th century, but proves sufficiently general to account for contemporary populist ascendancy. Particularly important and pertinent - though fragmentary and in need of many additions - are Max Weber's analyzes, especially those referring to charismatic leadership in transition towards more bureaucratic forms. Such transitions result in "plebiscitary leadership" and chaotic "plebiscitary politics".

Populist movements and their leaders

Weber saw social movements, especially "big" religious and political movements, as unstable, yet powerful driving and direction-setting forces of history. Heemphasized the role of charismatic leaders-reformers as the key social mobilisers and drivers of such movements. Radical 
attitudes of such leaders, their charismatic nepotism, demagogy and unpredictability all propel the movements politically and weaken their organisational effectiveness. Therefore all movements face a political dilemma: either they wither away as political force or they transform into more organised parties and regimes.

“Plebiscitary leadership" - a phenomenon similar to modern populism - is a "transitory" form of leadership that accompany a change of mass protest movements led by demagogic "mobilisers" into organised political parties capable of controlling the state. They are "half-wayhouses" in transition from mass protest movements and their demagogic leadership towards mass parties and their bureaucratic leadership. Such transitions are, in Weber's eyes, the result of both 'bottomup" expectations and "top down" impositions (1978, pp. 1116-1150).

Weber saw plebiscitary movements and their demagogic leaders as cyclical and transitory phenomena. They form a kind of "waves" of contestation in which the early mobilisations go in tandem with rapid social changes and political crises. Populist (plebiscitary) leaders undermine socio-political order they attempt to repair, and they provoke competitive ("backlash") movements. This leads to political crises and replacements of populist critics-mobilisers by more organisationally skilled leaders. At the same time, the protest movements transform into more stable and "routinized" forms: parties or regimes.

Plebiscitary movements and their demagogic leaders - sarcastically referred to by Weber as "servants of the people" - represent "the most important type of transition" of leadership and political domination - a sort of link between the charismatic and bureaucratic leadership (1978: 267). The former is based on followers identifying the leader with the highest values. The latter is based on the rational-legal legitimation, and it is typical of modern party organizations. The transitory "plebiscitary" leadership emerges in conditions of weak political organization and strong bottom-up pressure for democratic "representation". Such 
leadership is based on popularity that must be perpetually rebuilt, on public acclamation and trust in a spontaneous, proto-democratic manner, as such freed from legal and on democratic accountability and control. Plebiscitary leaders act as self-styled and direct representatives of the "will of the people", which, in turn, is generated through direct demagogic appeals, usually saturated with emotions. Social movements mobilized by such leaders are radical, leader-centric and fragile (Ibidem, pp. 241-71, 1111-1155).

The plebiscitary form of power (domination), typical of protest movements, also extends to the administrative "team" that forms around the leader. It resembles a "lose circle of loyalists", rather than an organized group. The "team" consists of the leader's closest and most trusted associates and those who gain popularity of "the people" through criticism of the ruling elite and the contestation of the established political order. Such leadership recruitment suppresses the process of bureaucratization and results in the plebiscitary movements' giving rise not so much to political parties as highly informal clientelist leadership cliques.

Members of such cliques are stratified according to their "popularity among the people" and according to the trust of the leader. They can be "recalled" (dismissed) if their popularity or trust of the leader is gone. This makes the structure of plebiscitary movements informal and fluid, as its organizational foundations are poorly formalized. This weakness, in turn, makes it hard for party organizations or parliaments to exercise control over populist leaders and their "teams". This explains the weak party discipline, administrative dilettantism, the lack of a coherent strategy of action and the organizational chaos that usually accompanies plebiscitary politics (Ibidem, pp. 267-71, 289-92, 1126, 1451-60). This is why the takeover of power by populist leaders leads to political 
degeneration of entire power elites. Populist (plebiscitary) - and therefore clientelistic - recruitment causes negative selection to the highest state administration and economic leadership positions.

Populist (plebiscitary) selection favours "the type of people who are the most spectacular, who promise the most, who use the most effective methods of propaganda in competition for power" (Ibidem, p. 268). Therefore populist leaders prove calamitous reformers. They may be effective wreckers of established political orders, but they seldom deliver on their promises of "constructive change". Their actions hinder the process of rational organization, both in politics, as well as in the economy. Moreover, they undermine rule of law in the system of justice and state administration. The introduction of "principles of social justice into the economic sphere" makes the plebiscitary "administration of justice emancipated from formal procedures". Politics becomes a struggle with critics and opponents, a competition in unrealistic promises backed by mass manipulation of emotions. Mutual trust among the top politicians and state administrators gradually evaporates. The rule of law and formal procedures underlying systems of governance in modern states are gradually weakened.

Populist movements weaken not only the quality of political elites, but also undermine the key political institutions: efficient state administration, the rule of law, and the electoral mechanisms that enforce democratic accountability of politicians. State administration is infected by clientelism that undermine administrative competence. Rule of law is replaced by arbitrary decisions of leaders. Elections become exercises in mass pledges of loyalty. This puts populist leaders in a paradoxical situation: on the one hand, they present themselves as mouthpieces of "ordinary citizens"; on the other, they undermine the very principles of pluralistic and tolerant liberal democracy. This emphasis on destabilizing effects of plebiscitary leadership is one of the distinguishing features of the Weberian research perspective. 
As Weber repeatedly emphasizes, plebiscitary movements and leadership are short-lived. The main cause of their impermanence is chaos, incoherence and uncertainty - typical nails in the coffin of the "plebiscitary democracy" born of them. However, before such movements expire and their leaders are replaced by more professional politicians, governments are weakened, political elites lose their trust, and the state and its organs plunge into administrative chaos. Therefore, the cycles of successive mobilizations, crises and bureaucratic stabilization correlate with the periodic weakening of the effectiveness of power elites and political institutions.

Contemporary populist leaders and political elites

Contemporary populist leaders base their careers on criticising established political elites and contest socio-political order shaped by these elites. Such leaders, and the movements they mobilize, are united "against", rather than "for". They share their contempt for established elites and their politics, both blamed for the real or imaginary problems. This negative foundation of unity results in polarising politics: who is not with us is against us. It also contributes to fragility of such movements and their leadership. When it comes to the formulation of positive goals, desired solutions, the movements divide and is prevented from falling apart into hostile political parties or factions by increasingly autocratic leaders.

Populist leaders emerge at the times of rapid change and social crises, and the current crop of populist leaders gained public attention and support by criticising the disastrous consequences of the 2008-2012 economic slowdown and the chaos caused by the waves of political migrations, both labour migrations and waves of refugees. Both these "disruptions" were managed badly by political establishments in advanced societies, and they provided good windows of opportunity for populist 
critics of "economic precariousness", various "austerities" imposed in "debtor countries" and, above all, "invasions" by foreign workers and refugees. Neither the national governments nor the EU could cope with the political fallout from these disruptive processes which spiralled into crises.

Populist demagogues are both symptoms of such crises - which sociologists of political institutions often label political-institutional "decay" (e.g. Fukuyama 2016) - and the causes of the deepening crisis of authority. They divide and polarise political leadership, and this makes them parts of the mechanism driving the crisis cycle. The promises of quick and easy fix that populist leaders make cannot be fulfilled. Yet, the charisma of such leaders is dependent on their capacity to deliver the promised outcomes. When crises deepen, populist leaders cannot escape responsibility and blame - and they fall on their swards. However, against the expectations of liberal democrats, the successor leaders are typically tougher and more authoritarian than their predecessors.

Maintaining mass support, mass involvement, participation in demonstrations, pickets etc. is extremely difficult. It requires regular demagogic "reinforcements" in the form of appeals, speeches, acts of sacrifice and, above all, immediate "neutralization" (if not annihilation) of critics and competitors. This fragility of populist leadership, the high cost of mobilization, and thus the instability of movements, is the biggest problem faced by populist leaders. Incapable governance, usually based on demagogy and manipulation, leads to rapid demobilization of the movement. Such "fading" movements are eventually transformed under the pressure of political clients - into "parties of power", and demagogue leaders are transformed into autocrats.

Hence the frequent and early attempts to transform populist movements into more permanent and "routinized" - and thus easier to maintain organizational forms; parties, factions or interest groups. It is a process 
full of risk, because the "routinization" and organization of movements is usually accompanied by internal schisms and divisions. The unity in opposition and protest does not translate into a common goal. Whenever the leaders of the movement gain power, are forced to formulate programs and strategies, or fill influential positions with loyal supporters, it is often accompanied by conflict and rift. Charismatic "thunderbolt throwers" often turn out to be strategic dilettantes or, even worse, fantasizers, yet they do not easily give up leadership roles and often choose the path of authoritarianism that leads to autocratic dictatorship.

Weberian analyzes draw attention not only to the "crisis-evolutionary" sources of populist movements - seen as an aspect of the mass democratization process, as a form of collective protest mobilized topdown by skilled demagogues, and as transitional forms in political cycles (charisma- bureaucracy) - but also to the rhetoric and its reception, emotional involvement, and the strategic role of the demagogic leaders and their "ruling" teams. Populists build their credibility and support on attacking political establishments, on breaking the rules and conventions of political competition, on dividing and polarising the political scene. They are both symptoms and causes of the periodic weakening of power elites. They herald divisions within ruling elites, and they contribute to the declining effectiveness of governance. Invariably, populist demagogues turn out to be weak politicians: as individual leaders and as national "leadership groups".

As individuals, they show few "elite qualities", such as political talent, competence and good performance. They give satisfaction to those who treat politics as a vent for their own frustrations and resentments, but they do not prove themselves as "statesmen", parliamentarians, party activists or administrators of a modern state. By their very nature (as "elite" and establishment's "critics") they are "outsiders", lacking not only knowledge and experience, but also the ability to successfully 
govern. They are usually masters of critique, and negative politics, but also dilettantes poorly prepared to constructive politics. Their actions deepen economic crises and social divisions, exacerbate conflicts and, as a result, lead to a crisis change of the regime or dictatorship. In this sense, populists act as a vanguard of political decay and autocratic dictatorship.

However, the most important shortcomings of populist leaders are collective-structural in nature. They are unable to form collaborative ruling "teams". They undermine - and ultimately destroy - the intraelite trust. Such trust, and the resulting political moderation, the shared respect for rules and conventions of peaceful political competition, are hallmarks of effective and cohesive elite. One may say that such mutual trust - and the resulting capacity to cooperate, negotiate decisions and resolve conflicts - is a sine qua non condition of effective politics.

\section{Conclusions}

"Culturalist" and "institutionalist" explanations of populist movements, we argue, need to be supplemented with "leadership-focussed" and "actor-centered" explanations. Specifically, attention should be given to populist leaders who act as pied pipers offering irresponsible and undeliverable promises, and exhibiting hatred for their rivals, contempt for the ruling conventions, and disdain for the rule of law. They muscle themselves into the elite ranks using combative and manipulative demagogy, and by circumventing the typical elite channels of recruitment. Individually, they often lack "elite qualities" understood as political excellence, as high skills in negotiation, collaboration and compromise.

Collectively, they lack trust and respect for established "rules of political engagement". Under their influence, politics become a tough, combative, emotionally charged and unpredictable. Populist leaders attack and fracture established elites, polarise politics and antagonize 
elite segments. They change the normatively regulated "political game" into hostile confrontation, often open warfare. While the extent to which populist leaders act in this way differs from country to country, all show the preference for confrontation over collaborative compromise. The proliferation of populist critics of political establishments mark a progressive political decay: the declining effectiveness of the state, demise of the rule of law, and weakening of electoral mechanisms of democratic accountability. These three central political institutions usually sustained and reinforced by political elites - are now undermined by ascendant populist leaders and movements.

The wave of populism that is sweeping through Europe and North America is a serious test - a challenge for modern sociology of politics. The analytic and theoretical apparatuses of this branch of sociology looks poorly prepared for this challenge. They are still influenced by preferences and prejudices of the last century. They produce certain blind spots in sociological analysis of politics: unwillingness to include in this analysis the key political actors, and examine the characteristics of leadership groups: their political styles, internal structure, openness and social cohesion.

\section{References}

Barr R.R. (2009), Populists, outsiders and anti-establishment politics, "Party Politics" Vol. 15, No. 1

Betz H.-G. (1994), Radical Right-Wing Populizm in Western Europe, Macmillan, London

Canovan M. (1981), Populism, Harcourt Brace, New York

Canovan M. (2004), Populism for political theorists?, "J ournal of Political Ideologies" Vol. 9, No. 3 
Della Porta D., Diani M. (1999), Social Movements: An Introduction, Blackwells, London

Fukuyama F. (2016) Political Order and Political Decay, Farrar, Straus and Giraux, New York

Gerbaudo P. (2014), The Mask and the Flag. Populism, Citizenism and Global Protest, Hurst, London

Populism: Its Meaning and National Characteristics (1969), (Eds.) Ionescu G., Gellner E., Weidenfeld and Nicolson, London

Mudde C. (2015), Populism in Europe: a Primer, Open Democracywebsite, https:// www.opendemocracy.net/ can-europe-make-it/ cas-mudde/populism-in-europe-primer

Muller J .-W. (2016), Capitalism in One Family, "London Review of Books" Vol. 38, No. 23

Norris P., Inglehart R. (2016), Cultural Backlash: Trump, Brexit and Authoritarian Populism, Harvard University Press, Cambridge

Pakulski J . (1991), Social Movements: The Politics of Moral Protest, Longman Cheshire, Melbourne

Shils E. (1956), The Torment of Secrecy, Heinemann, London

Smelser N. (1981), Sociology, Prentice - Hall, Englewood Cliffs - NewYork "The Economist" (2016), Post-truthpolitics in the age of social media, September 10

Weber M. (1978), Economy and Society, University of California Press, Berkeley 